\title{
Effect of Budget and Product Attributes Against Consumer Preferences (Survey on the village community Padasuka Bandung)
}

\author{
Hadi Alamdhien, Hamdan Ardiansyah, Bagus MDES \\ Universitas Pendidikan Indonesia \\ Bandung, Indonesia \\ hadi.alamdhien@student.upi.edu
}

\begin{abstract}
The problem of this research is there are so many people who use Honda Beat motorcycle in last one year. It is because the behavior of consumers who have high preference towards Honda Beat motorcycle compared to the other motorcycles. Preferences can be seen from the consumers' budget to buy a motorcycle and Honda Beat's product attributes. Subjects of this study are Honda Beat motorcycle users in Kelurahan Padasuka Bandung with 100 Honda Beat users as the samples. The method used in this research is an explanatory survey using questionnaire as data collection tool. Simple linear regression is used for the data analysis technique by applying Eviews 6 program. The research result shows that a budget variable has negative correlation and insignificant on preferences. This is because consumers have been helped by credit system so high and low budget does not affect the consumer to have a Honda Beat motorcycle. However, a product attributes variable have positive correlation and significant on preferences. This means that the higher quality of Honda Beat attributes affect the higher consumers' preferences on goods and services. In addition, Honda Beat motorcycle users are satisfied with the features, quality, reliability and service provided compared to the other motorcycles' attributes. Hence, product attributes will influence consumer preferences level to Honda Beat motorcycle.
\end{abstract}

Key words: Preference, budget, product attributes

\section{INTRODUCTION}

City is the concentration of various human space activities. The residence and activities of the urban population spread in different locations causing tissue interaction in it. Frequent interactions causing their high mobility.

In this context, the existence of infrastructure is very important. Transportation is no longer limited to moving goods and people from one place to another. Furthermore, transportation is a key element forming the city that is closely related to many things, including the activities of the economy, human health, and even the environment. Good transport in terms of smooth, safe, convenient, and cheap may reflect the state of the city is good

Community needs for transport is important for the present and future. The choises of transportation is very various kinds depending on the place and its use, for example, land use bus transportation, sea transportation by ship and air transportation is by plane. One preferred means of land transport to facilitate and accelerate the journey that is using motorcycles.

At this time the need of motorcycle for the community is vital for the level of congestion is very severe on the highway, making it an alternative for people to cope with congestion is to use a motorcycle to reach the destination in town and this is a very appropriate choice compared to the means of other transportation.

Motorcycle demand for people has increased from year after year, it provides an opportunity for motorcycle manufacturers to increase innovation and technology of the product to provide a motorcycle superior to society. Each manufacturer was producing motorcycles with new designs according to the times and the desire of consumers.

With the development of technology and the Indonesian people who do not want tough and easy to use then the producers issued a number of motorcycles in the form of automatic and non- automatic. The development of these two types of motorcycle is dependent on the desire of consumers every era wants to feel the lifestyle of driving different.

Data from the Indonesian Motorcycle Industry Association (AISI), motorcycle sales in the first quarter 2013 reached 1,970,823 units and 1,232,503 units or 62.54 percent are automatic type [1]. that the public interest to buy motorcycles tend to choose the type of automatic and brands that major to purchased are Honda Beat as many as 453822 units and in second place is also just a half of it from Honda Beat are Honda Vario Techno 125 of 276482 units sold in Indonesia. There also with other brands that are very far from total sales of Honda Beat motorcycle brands this year.

Based on these results the authors conducted interviews to the marketing department of PT. Daya Adira Mustika that are on the Jalan Raya Cibeureum where these companies are main dealer center of Honda motorcycles [2]. The results of the interview was confirmed that the market share of Honda Beat motorcycle is very large compared to other motor types, at least $50 \%$ of the total sales for each dealer spread. They also found a growing number of residents will make the motorcycle sales more growing also. Therefore they recommend dealers are in the city who have sales large enough are in the region of cicadas Padasuka village that famous for a large population.

Honda Beat motorcycle sales at PT. Subur Motor Raya is located in the village of Padasuka amounted to 1180 units ( $62 \%$ ) and is clearly in accordance with that has been said by 
marketing PT . Daya Adira Mustika that Honda Beat motorcycle sales of more than $50 \%$ of total sales [3].

Seeing these conditions where too many people who buy a Honda Beat motorcycle brands compared to other motor types and the many factors that influence. According Phydick theory of consumer behavior is a description of how consumers allocate income between the goods and services are different in order to maximize their welfare [4] and according Eeng Ahman that the usability of a product needs not be measured, but enough to know and consumers are able to make high and low order (preferences) to power obtained from consuming a bunch of stuff [5]. Based on the theory that consumer behavior can be understood through three steps, consumer preferences, budget constraints, and consumers options.

\section{THEORETICAL FRAMEWORK}

Consumer behavior is the behavior of consumers in the market in determining the choice (preference) for goods to be bought. Consumer behavior occurs due to limited income, while the desire for unlimited consumption. This causes consumers should be more selective in choosing the goods in accordance with the will, the ability to purchase goods and in accordance with what is needed. Another objective of consumer preference is to describe the reasons why people prefer the goods than the other goods. In understanding consumer behavior, there are three steps namely consumer preferences, budget line, and the choice was finally set.

Preference is the ability for consumers to sort high to low power utility derived from consuming a bunch of stuff ( Eeng Ahman and Yana Rohmana , 2009: 128 ).

Consumer preferences can be illustrated by the indifference curve. Consumer equilibrium occurs when the indifference curve and the budget line intersect. Indeferensi curve shows all combinations of market baskets that provide the same level of satisfaction to someone.

Paul Samuelson introduces real preference theory (Revealed Preference) which aims to enhance the ordinal theory. He stated that the efficiency can be measured and weaknesses ordinal approach, namely by accepting the assumption of convexity (curvature of the curve) of negative indifference curve. According to Paul Samuelson that the revealed preference theory is applicable if their rationality, consistent, the transitive principle and revealed preference Axioma [6].

The theory of preference revealed shows how the attitude of a person in determining the choices when prices and income vary can be used to determine consumer preferences. An individual in making a choice (preferences) were first considered is its budget.

Budget is the amount of money that is owned by someone and then arranged systematically for the allocation of expenditure in the period or specific time [7]. This is because each individual will use the limited budget for the purchase of goods to be chosen in the hope of obtaining maximum satisfaction.

The relationship between the budget and preferences can be known only after knowing enough information, such as prices of goods. After that, consumers have a choice of one basket market compared to other basket markets, if the chosen basket market is cheaper compared to other market basket, then consumers will prefer the chosen market basket. This happens because the consumer is facing their financial constraints.

It can be concluded that if the budget which is owned by an individual to increase, then the preferences that do will increase. On the contrary if the budget you have little, then the preference is done would be more restricted, so that consumers are not free to choice. Based on the above exposure in the prediction that the factors influencing the preference are budget.

Furthermore, beside the budget, preferences are also influenced by the product attributes. As said by Donald R. Lehmann and Russell S. Winer that consumers have a different attitude in looking at the attributes that are considered relevant and important. They will give the greatest attention to the attributes that provide the benefits sought. Market a product often can be segmented based on attributes that stand out in the group of consumers that is different [8] .

Attributes are the characteristics possessed by a product that will be selected by the consumer. Consumers usually determine the choice of a product seen on the qualities of the product itself. There are several dimensions that can be used to analyze the quality of the product that is characteristic of the performance, features, reliability, performance, durability, service capabilities, aesthetics, and perceived quality. However, in this study the researchers limited the dimensions under consideration, because not all dimensions can be used to analyze the quality of the products owned by Honda Beat motorcycle brands.

Based on the above exposure can be described as the following framework:

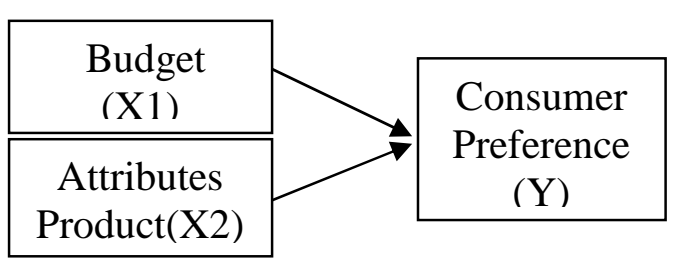

Fig. 1. Theoretical Framework

Based on these descriptions, the authors in this study chose the budget and the product attributes that influence consumer preference towards the brand Honda Beat motorcycle.

\section{RESEARCH METHODS}

This study reveals about the factors that influence consumer preferences towards consumer brands Honda Beat motorcycle. Objects in this research that consumers' preferences as the dependent variable ( $\mathrm{Y}$ ), while the budget and product attributes as independent variables ( $\mathrm{X} 1$ and $\mathrm{X} 2$ ) . The subject or the survey respondents are Padasuka Village community in Bandung.

The method used by the authors in this study is the method of explanatory or explanatory survey. Survey research is research that takes a sample from a population and using questionnaires as a data collection tool that the principal intended to explain the causal relationship between the variables studied [9]. But in this study was limited to a 
sense of survey research data was collected from a sample, to represent the entire population.

Sampling technique used in this research that pursosif sampling techniques (based on certain considerations) and a proportionate stratified random sampling technique (random) [10] with a 11.720 population [11].

Determination of the sample is done by using Taro Yamane formula [12]. From the calculation above, then obtained a minimal sample size in this study as many as 100 people.

\section{DATA ANALYSIS RESULTS}

This study using parametric statistical analysis techniques with simple linear regression analysis that have utility to determine the degree of association between one or more independent variables with the dependent variable. Data analysis technique is used to test hypotheses and determine the effect on the budget and preference of product attributes Honda Beat motorcycle brands in the Village Padasuka Bandung.

The independent variables in this study are budget (X1) and product attributes (X2), while the dependent variable in this research is consumer preference $(\mathrm{Y})$ having the size or scale of different data. For variable budget is seen by expenditure in use for motorcycles data while the ratio for the variable shape consumer preferences and product attributes shaped ordinal data.

To meet some of the requirements which the parametric analysis of data at least scale interval, then the data is transformed into ordinal and interval data simplest technique using MSI (Method of Successive Interval) ". Therefore, the research data results of questionnaires that are ordinal namely consumer preferences $(\mathrm{Y})$ and product attributes (X2) is converted into interval data using the MSI (Method of Successive Interval).

Budget variable (X1) in this study unit is Rupiah (Rp). For koefisisen regression calculation is done with the help of program Eviews 7.

The results of data processing can be inferred that the regression model in consumer preference for the brand Honda Beat motorcycle is as follows:

$\mathrm{Y}=9.114615-0.120549 \mathrm{X} 1+0.584758 \mathrm{X} 2$

$\mathrm{Se}=(2.805469)(1.504805) \quad(0.067928)$

$\mathrm{t}_{\text {Hitung }}=(3.248875) \quad(-0.080110)$

$(8.608511)$

$\mathrm{f}_{\text {Hitung }}=37.34682$

$\mathrm{R}^{2} \quad=0.435040$

$\mathrm{R}^{2}$ adjusted $=0.423392$

Dw $=1.820834$

Where:

$\mathrm{Y}=$ Consumer Preferences

$\mathrm{X}_{1}=$ Budget

$\mathrm{X}_{2}=$ Product Attributes

From the equation above it can be seen the significance of each regression coefficient as follows :

a. The constant regression equation is 9.114615 , meaning that if there is no independent variable ( $\mathrm{X}$ ), then consumer preferences obtained is equal to 9.114615 one unit preferences.

b. The regression coefficient for the budget ( X1) of 0.120549 means that whenever there is an increase in the budget of one million rupiah, the preferences of consumers will be reduced by 0.120549 one unit preferences.

c. The regression coefficient for the product attributes ( $\mathrm{X} 2)$ is 0.584758 means that whenever there is an increase of one unit of product attributes, hence the preference of consumers will increase by 0.584758 one unit preferences.

Testing this hypothesis through $\mathrm{t}$ test, the error rate used by the author of $5 \%$ or 0.05 at the $95 \%$ significance level with df $=\mathrm{nk}-1(100-2-1)=97$. The results in Table $4.13 \mathrm{t}$ test results $t$ test using Eviews 7 of each independent variable ( budget and attributes of the product ) is as follows :

a. Variable X1 (budget ) obtained t count for -0.080110 while $\mathrm{t}$ table of 1.660 . It shows that thitung $>\mathrm{t}$ table $0.080110>1,660$ ) or in other words $\mathrm{H} 0$ is accepted and Ha rejected, which means that the budget and no significant negative effect on consumer preferences .

b. X2 ( product attributes ) obtained t count amounted to 8.608511 while ttable 1,660 . It shows that tcount $>\mathrm{t}$ table $(8.608511>1.660)$ or in other words H0 rejected and $\mathrm{Ha}$ accepted, which means that the budget positive and significant impact on consumer preferences .

Based on test results obtained Fhitung 37.34682 with $\mathrm{df}=$ n-k-1 (100-2-1) = 97 obtained Ftabel at 3.11 and the significant level of $10 \%$ or 0.1 . It shows that $\mathrm{F}$ count $>\mathrm{F}$ table (35.385> 3.11) or in other words $\mathrm{H} 0$ rejected and $\mathrm{Ha}$ accepted which means that the independent variable (budget and attributes of the product) together influence the dependent variable (consumer preferences).

Based on estimates of Eviews, obtained R2 values of 0.435040 , or 0.435 , meaning that the regression line is able to explain $43.5 \%$ of the facts and the remaining $56.5 \%$ is explained by other variables. In other words it can be said that consumer preference variables able to be explained by the variable budget and product attributes only $43.5 \%$ and the remaining $56.5 \%$ is explained by other variables outside variables studied.

\section{RESEARCH RESULT}

From the analysis of research data and test hypotheses known that budget and no significant negative effect on the preferences Village community needs Padasuka Bandung. It means someone big or small budget does not affect the preferences of its needs for Honda Beat motorcycle.

Budget is basically one of the variables that can affect a person's preference. But in this study budget variable does not affect the consumer's preferences Honda Beat motorcycle.

Given budget constraints, then each individual must be able to sort out all the requirements to the sort of needs that really needed to override the current interests and needs that are not necessary. But in the selection of motorcycles, especially Honda Beat, the budget can not take effect because that one's budget limitation against other needs can be assisted by the producer with credits that are tailored to the consumers' ability to pay Honda Beat motorcycle. Consumers who have a low budget can choose a loan or mortgage long enough for 35 months or even consumers who have a higher budget could reduce the term of repayment by paying more each month can even buy it with cash. 
According Moch. Hatta that purchase with cash and credit should be prohibited because it moves the hearts of people to buy beyond their ability '[13]. Here it could be explained that with the credit system then someone would exceed its limits as well as the purchase of Honda Beat motorcycle is not limited to the budget which is owned by the public so anyone can have a Honda Beat motorcycle. And this is contrary to the theory of the budget to consumer preferences by Pyndick (2010: 09) that the basic idea is simple about the relationship between the budget and preference after knowing enough information when a consumer determines the choice of a market basket rather than market basket more, and if the market basket selected cheaper compared with a basket of other markets, consumers definitely prefer the chosen market basket that. At the present time also people who want a Honda Beat motorcycle can be made easier to have it with their down payment is low and there are also swapped the previous motor used as a down payment to have a new motorcycle. So it can be concluded that the budget for any one can get a Honda Beat motorcycle and facilitated by the motorcycle dealers.

Based on the results of statistical calculations using multiple linear regression method is known that the product attributes positive and had significant impact on consumer preferences in the Village community Padasuka Bandung. This means that the higher the quality of the attributes of the Honda Beat motorcycle, hence the preference made by consumers for goods and services will grow (increase). People in the village Padasuka Bandung feel that the product attributes supplied by Honda Beat felt pretty good number of respondents agreed and strongly agreed and in accordance with the indicators consist of performance, features, reliability, perceived quality, and service capabilities but Village community Padasuka City Bandung see Honda Beat motorcycle attributes of quality and comfort of the bike compared to the features and performance. According to Donald R. Lehmann and Russell S. Winer Consumers have different attitudes - different in looking at the attributes attributes that are considered relevant and important. They will give the greatest attention to the attributes that provide the benefits sought. Market a product often can be segmented based on attributes that stand out in a group of consumers that is different. Thus, people already thought to behave rationally in determining the choice of motorcycles that will be used.

Attributes of products is one of the elements that affect consumer preferences. Someone wants to obtain the satisfaction not only of goods or services purchased, but also on the attributes or characteristics possessed by these goods and services. This explanation is in accordance with conditions or behaviors Padasuka Village community in choosing motorcycle racing to the dimension of product quality. The public more confidence with Honda Beat motorcycle because of the quality and durability of the engine better plus also their 3-year warranty, the driving comfort Honda Beat motorcycle is in accordance with the public compared to other motorcycles, and also with the great brand of Honda from old where the sale price still high compared to other motorcycles.

\section{CONCLUSION}

Based on the research results and the results of the discussion about the effect of budget and product attributes to consumer preferences can be summarized as follows:

1. Preference is done by the people in the choice of motorcycles that are used are considered good. This means that the average Village community Padasuka Bandung more who use Honda Beat motorcycle compared to other motorcycles.

2. Budget have negative effect(budget) and no significant effect on consumer preference towards Honda Beat in Sub Padasuka Bandung. This means that the budget does not affect the consumer's preferences Honda Beat.

Product attributes positive and significant impact on consumer preferences towards Honda Beat in Sub Padasuka Bandung. This means that the better or more features, product reliability, the ability of the services provided, and also the quality perceived by the consumer, hence the preference made by consumers will increase.

\section{REFERENCES}

[1]. Asosiasi Industri Sepeda motor Indonesia (AISI)

[2]. PT. Daya Adira Mustika Honda

[3]. PT. Subur Motor Raya Honda

[4]. Pindyck, Robert S dan Daniel L Rubinfeld. (2009). Mikroekonomi edisi keenam. Jakarta: Indeks.

[5]. Ahman, Eeng dan Rohmana, Yana (2009). Teori Ekonomi Mikro, Bandung : Laboratorium Ekonomi dan Koperasi.

[6]. Joesron, Tati S \& M.Fathorrozi. (2003). Teori Ekonomi Mikro. Jakarta: Salemba Empat.

[7]. Mowen, John C dan Michael minor. (2002). Perilaku konsumen. Jakarta: Erlangga.

[8]. Iis Aisyah. (2011). Faktor-Faktor yang Mempengaruhi Preferensi Konsumen (Studi Pada Mahasiswa di Kota Bandung). Vol.6 No.2 2011. [28 Juni 2013]

[9]. Sugiyono. (2009). Metode Penelitian Kuantitatif Kualitatif dan $R \& D$. Bandung: Alfabeta.

[10]. Arikunto, Suharsimi. (2006). Prosedur Penelitian Suatu Pendekatan Praktik. Jakarta: Rineka Cipta.

[11]. Kelurahan Padasuka Kota Bandung

[12]. Riduwan. (2004). Dasar-dasar Statistika. Bandung: Alfabeta

[13]. Tarsius Haria. Selayang Pandang Koperasi. Tersedia: http://tarsiusharia92.blogspot.com/2013/07/koperasi.ht ml/ [Juli 2013]

[14]. Nicholson, Walter. (2000). Mikroekonomi Intermediate dan Aplikasinya. Jakarta: Erlangga.

[15]. Bilson Simamora. (2004). Panduan Riset Perilaku Konsumen. Jakarta: PT Gramedia Pustaka Utama. 
Journal

[1]. D. Mackison, A.S Anderson, \& W.L Wrieden. (2009). Consumer Preference for energy, salt, fat and ingredients information in catering outlets. 2 juli 2009.

[2]. David R. Bell \& James M. Latin. (1998). Shopping behavior and consumer preferences for store price format: why "large basket" shopper prefer EDLP. Marketing Science. Vol.2 No.1 1998. Halaman 66-88.

[3]. Ibiyanto, Hariadi (2008). Analisis faktor-faktor yang mempengaruhi keputusan konsumen dalam membeli sepeda motor merk yamaha mio (studi kasus di PT. Alfa Scorfii Medan). Tesis Sekolah Pascasarjana Universitas Sumatera Utara Medan.

[4]. Kunto, Yohanes S \& Peter Remy P. (2006). Segmentasi gaya hidup pada mahasiswa program studi pemasaran Universitas Kristen Petra. Vol 1 No.1 april 2006, halaman 13-21.

[5]. Rahmani, Taufik A. Faktor psikologis, lingkungan dan bauran pemasaran yang mempengaruhi pembelian sepeda motor (Studi Pada Konsumen Sepeda Motor Merk Honda Beat 4-tak Merk Suzuki dan Honda di Kota Banjarmasin). Jurnal ISSN: 14110199 Wacana Vol. 13 No.2. April 2010, Fakultas Ekonomi Universitas Brawijaya Malang.

[6]. Sitti Rosipah, Burhan, Umi Purwandari. Preferensi konsumen terhadap pancake dari tepung sukun. Jurnal AGROINTEK Vol. 7 No. 1 Maret 2013, Jurusan Teknologi Industri Pertanian Universitas Trunojoyo Madura.

[7]. T.Sihol Nababan \& Basukianto. (2004). Paradigma teori permintaan dalam perspektif Filsafat ilmu. Vol.3 No.2 Agustus 2004.[online].tersedia: http://idjurnal.blogspot.com/2008/04/fokus-ekonomi-agustus2004-paradigma.html [11 Januari 2011]

[8]. Tedjakusuma, Ritawati. Sri Hartini dan Muryani. (2001). Analisis Faktor-Faktor yang Mempengaruhi Perilaku Konsumen Dalam Pembelian Air Minum Mineral Di Kotamadya Suarabaya. Jurnal Penelitian dinamika Sosial. Vol.2 No.3 Desember 2001. 12 Halaman.

.[online].tersedia:http://www.scribd.com/doc/1433945 7/Analisis-Faktorfaktor Yang-MempengaruhiPerilaku-Konsumen-Dalam-Pembelian-Air-MinumMineral. [ 11 Januari 2011]
Internet Sources

[1]. Atep Hendra Heriyawan. Ekonomi Koperasi. Tersedia:

http://ahendrahendriawan.blogspot.com/2011/10/ekon omi-koperasi-rangkuman-bab-1-sd-12.html/ [12 Oktober 2011]

[2]. Derry Mayendra. Teori preferensi konsumen. tersedia: http://derrymayendra.blogspot.com/2013/06/teoripreferensi-konsumen.html [26 Juni 2013]

[3]. Sandika Wahyu IP. Perilaku konsumen. tersedia: http://www.slideshare.net/crsandika/perilakukonsumen-14943654 [30 Oktober 2013]

[4]. Syafaat Muhari. Teori konsumsi perspektif konvensional dan ekonomi islam. tersedia: http://syafaatmuhari.wordpress.com/2011/09/05/teorikonsumsi-perspektif-konvensional-dan-ekonomiislam/ [5 September 2011]

[5]. http://id.wikipedia.org/wiki/Ekonomi

[6]. www.bps.go.id

[7]. www.proquest.com/pqdweb

[8]. www.find-docs.com

[9]. www.google.com 